\title{
Hypolipidaemic effect of maize starch with different amylose content in ovariectomized rats depends on intake amount of resistant starch
}

\author{
Xiong Liu ${ }^{1,2}$, Hiroshi Ogawa ${ }^{3}$, Taro Kishida ${ }^{1}$ and Kiyoshi Ebihara ${ }^{1}$. \\ ${ }^{1}$ Department of Biological Resources, Faculty of Agriculture, Ehime University, Matsuyama 790-8566, Japan \\ ${ }^{2}$ College of Food Science, Southwest University, Chongging 400716, China \\ ${ }^{3}$ Faculty of Human and Cultural Studies, Tezukayamagakuin University, 4-2-2 Harumidai, Minami-ku, Sakai-city 590-0113, \\ Osaka, Japan
}

(Received 18 December 2007 - Revised 21 April 2008 - Accepted 9 May 2008 - First published online 23 June 2008)

The effect of amylose content on digestibility of starch in the small intestine and on the concentration of plasma lipid were studied in ileorectostomized rats and in ovariectomized rats, respectively. Seven kinds of starch with different amylose content $(0,27,54,62,76,79,86 \%)$ were used as test starch, which contained $0 \cdot 4,5 \cdot 6,37 \cdot 1,40 \cdot 2,45 \cdot 6,36 \cdot 9$ and $36 \cdot 1 \%$ resistant starch (RS), respectively. Rats were fed one of test diets containing $30 \%$ test starch with different amylose content for $14 \mathrm{~d}$ in ileorectostomized and for $21 \mathrm{~d}$ in ovariectomized rats. Food intake was not significantly different among the groups. In ileorectostomized rats, the small intestinal starch digestibility decreased with increasing intakes of amylose and RS. In ovariectomized rats, body weight gain was lower on the higher amylose maize starch diets. The concentrations of plasma TAG and cholesterol decreased with increasing intake of RS. The concentrations of liver total lipids and TAG decreased with increasing intake of RS, but that of liver cholesterol did not. There was significant positive correlation between the level of sterol regulatory element-binding protein-1c mRNA and concentration of liver TAG. Total SCFA amount in the caecum increased logarithmically with increasing dry weight of caecal contents. The amount of bile acids in the small intestinal content and the excretions of bile acids and neutral steroids in faeces increased with increasing RS intake. These results show that starch rich in RS is more effective in preventing ovarian hormone deficiency-induced hyperlipidaemia.

Amylose content: Resistant starch: Ovariectomized rats: Plasma lipids: Bile acids

It is well known that lipid metabolism is influenced by sex hormones in animals and man ${ }^{(1,2)}$. Sex hormones such as oestrogen have a major impact on atherosclerotic processes. Oestrogen deficiency is associated with changes in cholesterol levels. Studies in animal models have shown that oestrogen inhibits the development of atherosclerotic lesions ${ }^{(3,4)}$.

Starch consists of two types of molecule, amylose and amylopectin. The amylose content is an important factor that determines the digestibility of starch. Starches with higher amylose content are found to be more resistant to digestion. The amylose content of starches is thus the major cause of resistant starch (RS) formation.

High amylose maize starch (HAMS) has been reported to reduce plasma cholesterol concentrations in rats ${ }^{(5-8)}$. The physico-chemical properties of HAMS are affected by RS content, which are expected to influence its physiological effects. HAMS is genetic varieties of starch containing over $40 \%$ amylose. However, it is not known if differences in the RS content in HAMS affects plasma cholesterol concentration in oestrogen-deficient rats. In addition, there have been few systematic studies of one kind of starch with different amylose/ amylopectin contents.
Therefore, in the present study, we compared the influence of maize starch with different amylose content on the change in lipid metabolism associated with oestrogen deficiency in ovariectomized rats.

\section{Materials and methods}

Test starches

Waxy maize starch (AL-0), normal maize starch (AL-27) and five kinds of HAMS (AL-54, AL-62, AL-76, AL-79, AL-86) were donated from the National Starch and Chemical Co. (Chicago, IL, USA). Amylose content was measured using commercial kits (Amylose/Amylopectin Assay Kit; Biocon Japan Ltd, Nagoya, Japan). RS content was measured using commercial kits (Resistant Starch Assay Kit; Biocon Japan Ltd). Amylose content of AL-0, AL-27, AL-54, AL-62, AL-76, AL-79 and AL-86 was 0, 26.8, $53.8,61.6,75 \cdot 7,78.9$ and $85.8 \mathrm{~g} / 100 \mathrm{~g}$, respectively. The RS content of AL-0, AL-27, AL-54, AL-62, AL-76, AL-79 and AL-86 was $0 \cdot 4,5 \cdot 6,37 \cdot 1,40 \cdot 2,45 \cdot 6,36 \cdot 9$ and $36 \cdot 1 \mathrm{~g} / 100 \mathrm{~g}$, respectively.

Abbreviations: CA, cholic acid; CDCA, chenodeoxycholic acid; CYP7A1, cholesterol $7 \alpha$-hydroxylase; CYP8B1, cholesterol 12 $\alpha$-hydroxylase; HAMS, high amylose maize starch; RS, resistant starch; SREBP, sterol regulatory element-binding protein; total-C, total cholesterol.

* Corresponding author: Dr Kiyoshi Ebihara, fax +8189946 9847, email ebihara@agr.ehime-u.ac.jp 


\section{Animals and diets}

The present study was approved by the Laboratory Animal Care Committee of Ehime University, and the rats were maintained in accordance with the Guidelines for the Care and Use of Laboratory Animals of Ehime University.

Wistar rats (Japan SLC, Hamamatsu, Japan) were housed individually in screen-bottomed, stainless steel cages in a room maintained at $23 \pm 1{ }^{\circ} \mathrm{C}$ with a $12 \mathrm{~h}$ light-dark cycle (light 07.00-19.00 hours). In the experiment, rats were allowed free access to one of the following seven diets: AL-0, AL-27, AL-54, AL-62, AL-76, AL-79 or AL-86 (Table 1). Body weight and food intake were recorded daily in the morning before replacing the food.

Experiment 1. Starch and RS digestibilities were examined in ileorectostomized rats. After acclimation to the AIN93Gbased diet without cellulose for $7 \mathrm{~d}$, Wistar female rats weighing about 200-230g were subjected to ileorectostomy in which the distal ileum is anastomosed to the rectum, described previously ${ }^{(9)}$. Rats subjected to the operation were not allowed food and water for the first $24 \mathrm{~h}$ after operation, and were intramuscularly injected with $0.01 \mathrm{ml}$ Mycillin Sol (containing procaine penicillin G $(200 \mathrm{~g} / \mathrm{l})$ and dihydrostreptomucin sulphate $(250 \mathrm{~g} / \mathrm{l})$; Toyo Jozo, Shizuoka, Japan) for the first $3 \mathrm{~d}$ after surgery. Then, rats were freely fed the AIN93G-based diet without cellulose for $10 \mathrm{~d}$. Constant growth rates $(5-7 \mathrm{~g}$ body weight gain/d) was achieved with this diet after $5 \mathrm{~d}$. After postoperative recovery, rats $(250-300 \mathrm{~g})$ were divided into six groups $(n 6)$ on the basis of body weight. Rats were allowed free access to one of the following six diets for $14 \mathrm{~d}$ : AL-27, AL-54, AL-62, AL-76, AL-79 or AL-86 (Table 1). Ileorectostomy effluents were collected for the last $4 \mathrm{~d}$ of the experimental period, freeze-dried and stored at $-50^{\circ} \mathrm{C}$ until analysis. Starch and RS digestibility was calculated as follows:

\section{Starch digestibility $(\%)$}

$$
=\frac{\text { starch intake }- \text { starch in ileorectostomy effluents }}{\text { starch intake }} \times 100 \text {. }
$$

RS digestibility (\%)

$$
=\frac{\mathrm{RS} \text { intake }-\mathrm{RS} \text { in ileorectostomy effluents }}{\mathrm{RS} \text { intake }} \times 100 \text {. }
$$

Starch and RS intakes were calculated from the food intake for the last $4 \mathrm{~d}$ of the experimental period, and from starch and RS content in each diet. The starch and RS contents in the diets and ileorectostomy effluents were determined using the commercial kits (Total Starch Assay Kit and Resistant Starch Assay Kit).

Experiment 2. Six-month-old female Wistar rats were acclimated by feeding a commercial solid diet (Roden Lab Diet EQ; PMI, USA) for $7 \mathrm{~d}$. After acclimation, rats were anaesthetized by intraperitoneal injection of sodium pentobarbital $(30 \mathrm{mg} / \mathrm{kg}$ body; Nembutal, Abbott Laboratories, Chicago, IL, USA), and bilaterally ovariectomized, after which they were randomly divided into seven groups ( $n$ 6), and were allowed free access to one of the following diets for $21 \mathrm{~d}$ : AL-0, AL-27, AL-54, AL-62, AL-76, AL-79 or AL-86 (Table 1). Before the animals were killed, faeces were collected from each rat on the final $4 \mathrm{~d}$ of the experimental period. The faeces were freeze-dried, weighed and milled.

On the last day of the experiment, a blood sample was collected from the neck of each rat at night into a blood collection tube (Vacutainer; Becton Dickinson, Franklin Lakes, NJ, USA) that contained heparin as an anticoagulant. The plasma was separated by centrifugation at $1400 \mathrm{~g}$ at $4^{\circ} \mathrm{C}$ for $15 \mathrm{~min}$, and was stored at $-50^{\circ} \mathrm{C}$ until analysis. After blood collection, the liver was immediately perfused with cold saline $(9 \mathrm{~g} \mathrm{NaCl} / 1)$, removed, washed with cold saline, blotted dry on filter paper, weighed and stored at $-50^{\circ} \mathrm{C}$ until analysis. After the liver was removed, the small intestine and caecum were removed. The contents of the small intestine were transferred into a pre-weighed tube, freeze-dried and weighed. The caecum was weighed, then $0.4 \mathrm{~g}$ of the caecal contents were transferred into a tube and $2 \mathrm{ml} 10 \mathrm{mmol}$ sodium hydroxide/l was immediately added and the mixture

\begin{tabular}{|c|c|c|c|c|c|c|c|}
\hline & \multicolumn{7}{|c|}{ Diet } \\
\hline & AL-0 & AL-27 & AL-54 & AL-62 & AL-76 & AL-79 & AL-86 \\
\hline Casein & 200 & 200 & 200 & 200 & 200 & 200 & 200 \\
\hline Maize oil & 70 & 70 & 70 & 70 & 70 & 70 & 70 \\
\hline Mineral mixture* & 35 & 35 & 35 & 35 & 35 & 35 & 35 \\
\hline Vitamin mixture* ${ }^{*}$ & 10 & 10 & 10 & 10 & 10 & 10 & 10 \\
\hline Celluloseł & 50 & 50 & 50 & 50 & 50 & 50 & 50 \\
\hline L-Lysine & 3 & 3 & 3 & 3 & 3 & 3 & 3 \\
\hline \multicolumn{8}{|l|}{ Maize starch } \\
\hline $\begin{array}{l}\text { AL-0 } \\
\text { AL-27 }\end{array}$ & 632 & $\begin{array}{l}332 \\
300\end{array}$ & 332 & 332 & 332 & 332 & 332 \\
\hline AL-54 & & & 300 & & & & \\
\hline AL-62 & & & & 300 & & & \\
\hline AL-76 & & & & & 300 & & \\
\hline AL-79 & & & & & & 300 & \\
\hline AL-86 & & & & & & & 300 \\
\hline Amylose content§ & 0 & $80 \cdot 4$ & 161.4 & $184 \cdot 8$ & $227 \cdot 1$ & $236 \cdot 7$ & $257 \cdot 4$ \\
\hline Resistant starch content $\|$ & $2 \cdot 5$ & $18 \cdot 1$ & $112 \cdot 6$ & 121.9 & $138 \cdot 1$ & $112 \cdot 0$ & 109.6 \\
\hline
\end{tabular}

Table 1. Composition of diets $(\mathrm{g} / \mathrm{kg})$

* Based on AIN93G ${ }^{(63)}$

†The vitamin mixture contained $20 \mathrm{~g}$ choline bitartrate $/ 100 \mathrm{~g}$

$\ddagger$ Cellulose powder, PC200 (Danisco Japan Ltd, Tokyo, Japan).

§Content of AL-0, AL-27, AL-54, AL-62, AL-76, AL-79 and AL-86 was 0, 26.8, 53.8, 61.6, 75.7, 78.9 and $85.8 \mathrm{~g} / 100 \mathrm{~g}$, respectively.

\| Content of AL-0, AL-27, AL-54, AL-62, AL-76, AL-79 and AL-86 was 0.4, 5.6, 37.1, 40.2, 45.6, $36 \cdot 9$ and $36 \cdot 1 \mathrm{~g} / 100 \mathrm{~g}$, respectively. 
was used for SCFA analysis; an aqueous solution containing $0 \cdot 5 \mathrm{~g}$ crotonic acid/l was used as an internal standard. The moisture level of the caecal contents was determined as the difference between the wet mass and the dry mass of the caecal contents after freeze-drying. The caecal wall was flushed with ice-cold saline $\left(9 \mathrm{~g} \mathrm{NaCl} / 1,4^{\circ} \mathrm{C}\right)$, blotted on to filter paper and weighed.

\section{Estimation of energy intake}

Energy from available starch, casein and maize oil was estimated to be $16.7 \mathrm{~kJ} / \mathrm{g}(4 \mathrm{kcal} / \mathrm{g}), 16.7 \mathrm{~kJ} / \mathrm{g}(4 \mathrm{kcal} / \mathrm{g})$ and $37.6 \mathrm{~kJ} / \mathrm{g}(9 \mathrm{kcal} / \mathrm{g})$, respectively. Part of the ingested maize starch that travels to the large intestine without being digested is utilized as a fermentation substrate by microflora, and is converted into various organic acids such as SCFA. The energy produced by fermentation of unavailable maize starch is estimated to be $7 \cdot 1 \mathrm{~kJ} / \mathrm{g}(1.7 \mathrm{kcal} / \mathrm{g})^{(10)}$. However, the digestibility of AL- 0 in the small intestine and in the large intestine was assumed to be 100 and $0 \%$, respectively. Energy intake in the experiment period was estimated as follows:

$$
\text { Energy intake }(\mathrm{kJ} / 3 \text { weeks })=\mathrm{P}+\mathrm{F}+\mathrm{DS}+\mathrm{UDS},
$$

where $\mathrm{P}$ is the energy from casein $=$ casein intake $(\mathrm{g} / 3$ weeks) $\times 16.7 \mathrm{~kJ} ; \mathrm{F}$ is the energy from maize oil $=$ Maize oil intake $(\mathrm{g} / 3$ weeks $) \times 37.6 \mathrm{~kJ}$; DS is the energy from starch digested in the small intestine $=$ Starch intake $(\mathrm{g} / 3$ weeks $) \times($ Starch digestibility in Expt 1$) / 100 \times 16.7 \mathrm{~kJ}$; UDS is the energy from starch digested in the large intestine $=$ Starch intake $(\mathrm{g}) / 3$ weeks $\times($ Starch digestibility in Expt $2-$ Starch digestibility in Expt 1)/100 $\times 7 \cdot 1 \mathrm{~kJ}$.

\section{Biochemical analysis}

The concentrations of total-cholesterol (total-C), HDL-cholesterol and TAG in the plasma were determined enzymatically using commercial diagnostic kits (Cholesterol E-Test Wako, HDL Cholesterol Test Wako and Triglyceride E-Test Wako; Wako Pure Chemical Industries, Osaka, Japan). The concentration of non-HDL-cholesterol was calculated by subtracting the concentration of HDL-cholesterol concentration from the total-C concentration.

The level of liver total lipids was determined gravimetrically after extraction by the method of Folch et al. ${ }^{(11)}$. The liver TAG and cholesterol concentrations were determined enzymatically as described elsewhere ${ }^{(12)}$. Steroids were extracted from the digestive contents (small intestine and caecum) and faeces by a mixture of chloroform-methanol $(1: 1, \mathrm{v} / \mathrm{v})$ at $70^{\circ} \mathrm{C}$ for $60 \mathrm{~h}^{(13)}$. The concentrations of bile acids in caecal contents and faeces were determined enzymatically by the $3 \alpha$-dehydrogenase assay method of Sheltaway $\&$ Losowsky ${ }^{(14)}$ using taurocholic acid as standard. The concentrations of cholesterol and coprostanol in small intestinal contents and faeces were analysed by capillary GLC (Model HP5890A; Hewlett Packard, Palo Alto, CA, USA) equipped with a flame-ionization detector and a capillary column $(30 \mathrm{~m} \times 0.53 \mathrm{~mm}$ inner diameter) coated with DB-1 (J\&W Scientific, Folsom, CA, USA) ${ }^{(15)}$. The oven temperature was $260^{\circ} \mathrm{C}$ and the flow rate of helium carrier gas was
$16 \cdot 9 \mathrm{ml} / \mathrm{min}$. 5 $\alpha$-Cholestane (Nacalai Tesque Inc., Kyoto, Japan) was used as the initial standard for neutral sterol analysis. The concentration and composition of bile acid in the small intestinal contents was analysed by capillary GLC (Model HP5890A, Hewlett Packard) equipped with a flameionization detector and a capillary column $(30 \mathrm{~m} \times 0.25 \mathrm{~mm}$ inner diameter) coated with DB-210 (J\&W Scientific ${ }^{(16)}$. The oven temperature was programmed to increase from 60 to $235^{\circ} \mathrm{C}$ at rate of $10^{\circ} \mathrm{C} / \mathrm{min}$ and the flow rate of helium carrier gas was $1.5 \mathrm{ml} / \mathrm{min}$. Nordeoxycholic acid (Steraloid Inc., Wilton, NH, USA) was used as the initial standard for bile acid analysis. Standard bile acids, cholic acid (CA), deoxycholic acid, 12-oxo-chenodeoxycholic acid, 12-oxolithocholic acid, chenodeoxycholic acid (CDCA), $\alpha$-muricholic acid, $\beta$-muricholic acid, $\omega$-muricholic acid, lithocholic acid, hyodeoxycholic acid and ursodeoxycholic acid were purchased from Steraloid Inc. The levels of caecal organic acids were measured using HPLC (LC-6AL; Shimadzu, Kyoto, Japan) by the internal standard method ${ }^{(17)}$.

\section{RNA extraction from the liver and RT-PCR analysis of gene expression}

Total RNA was extracted from frozen livers according to the method described by Chomczynski \& Sacchi ${ }^{(18)}$. RNA integrity was verified by agarose gel electrophoresis using Oligotex-dT30 (Takara Bio, Shiga, Japan). mRNA $(1 \mu \mathrm{g})$ was used for cDNA synthesis with $10 \mathrm{U}$ RT (AMV; Takara Bio) and $2 \mu \mathrm{l}$ oligo (dT) primer (Novagen Inc., Madison, WI, USA) according to manufacturers' instruction. Messenger RNA expressions of acyl-CoA cholesterol acyltransferase 1, acyl-CoA cholesterol acyltransferase 2, apoB, cholesterol $7 \alpha$-hydroxylase (CYP7A1), cholesterol 27hydroxylase, cholesterol $12 \alpha$-hydroxylase (CYP8B1), farnesoid $\mathrm{X}$ receptor, hydroxymethylglutaryl-CoA reductase, LDL-receptor, liver $X$ receptor, retinoid $X$ receptor, microsomal TAG transfer protein, sterol regulatory element-binding protein (SREBP)-1a, SREPB-1c, SREBP-2 and $\beta$-actin, as a housekeeping gene for normalization, were determined by real-time monitoring of a PCR using a Light Cycler instrument (Roche Diagnostics, Mannheim, Germany). cDNA ( $2 \mu \mathrm{l})$ was amplified in a total volume of $20 \mu \mathrm{l}$ using the $2 \times$ QuantiTect SYBR Green PCR Master Mix (Qiagen, Hilden, Germany) and specific primers at $0.5 \mathrm{M}$ each. After initial denaturation and activation of the polymerase at $95^{\circ} \mathrm{C}$ for $15 \mathrm{~min}$, cycling was performed for fifty cycles with annealing at the temperatures shown in Table 2 for $25 \mathrm{~s}$, synthesis at $72^{\circ} \mathrm{C}$ for $30 \mathrm{~s}$ and denaturation at $94^{\circ} \mathrm{C}$ for $15 \mathrm{~s}$. Fluorescence was measured at the end of the elongation step at $72^{\circ} \mathrm{C}$. The sequences of the gene-specific primers (Carl Roth, Karlsruhe, Germany) used in the study are listed in Table 2 .

\section{Statistical analyses}

Data are expressed as means and standard deviations ( $n$ 6). Data were analysed by one-way ANOVA using the Super ANOVA statistical software package (Abacus Concepts, Berkeley, CA, USA), and the differences among groups were examined by Tukey's multiple range test using Super ANOVA when the $F$ value was significant. $P<0.05$ was considered significant. 
Table 2. Primer sequence, product size and annealing temperature

\begin{tabular}{|c|c|c|c|c|}
\hline \multirow[b]{2}{*}{ Gene } & \multicolumn{2}{|c|}{ Primer sequence } & \multirow{2}{*}{$\begin{array}{l}\text { Product } \\
\text { size (bp) }\end{array}$} & \multirow{2}{*}{$\begin{array}{c}\text { Annealing } \\
\text { temperature }\left({ }^{\circ} \mathrm{C}\right)\end{array}$} \\
\hline & Sense & Anti-sense & & \\
\hline $\begin{array}{l}\text { Acyl-CoA cholesterol } \\
\text { acyltransferase } 1 \text { (ACAT1) }\end{array}$ & ATGTGGGAAGTAAATGAAGC & AAATACTAGCCAGACCGAAT & 193 & 53 \\
\hline $\begin{array}{l}\text { Acyl-CoA cholesterol } \\
\text { acyltransferase } 2 \text { (ACAT2) }\end{array}$ & CGGTCATGCTGATCCTCTTT & GTGTCACCAGCTCCCAAAAT & 204 & 55 \\
\hline apoB & TTGACACACTGAAGTTCCTA & ACATCAAACCCTGGTATTAG & 124 & 60 \\
\hline $\begin{array}{l}\text { Cholesterol } 12 \alpha \text {-hydroxylase } \\
\text { (CYP8B1) }\end{array}$ & ATGAAGGCTGTGCGAGAG & TCTCTTCCATCACGCTGTC & 127 & 59 \\
\hline $\begin{array}{l}\text { Cholesterol 27-hydroxylase } \\
\text { (CYP27) }\end{array}$ & CTCAAGAGACTGTCGGCAC & CTTCCTGGATCTCTGGGTT & 114 & 57 \\
\hline Farnesoid $\mathrm{X}$ receptor (FXR) & CGTTCAGCGGAGATTTTCAA & ATTTTCAGCTCCCCGACACT & 140 & 57 \\
\hline $\begin{array}{l}\text { Hydroxamethylglutaryl-CoA } \\
\text { reductase } \\
\text { (HMG-CoA R) }\end{array}$ & GCTGGTGAGTTGTCCTTGAT & CTTCTTGGTGCATGTTCCCT & 117 & 60 \\
\hline Liver $X$ receptor (LXR) & TGCTAATGAAGCTGGTGA & AGAGGACACGGAGAAACAGT & 144 & 57 \\
\hline $\begin{array}{l}\text { Microsomal TAG transfer } \\
\text { protein (MTP) }\end{array}$ & AGCGACATCACAGTGGACTC & GGCTCTCTTTTCTTCTCCGA & 223 & 62 \\
\hline Retinoid X receptor (RXR) & CAAACATGGGGCTGAACC & AGCAGGATGACCTGGTCGT & 148 & 57 \\
\hline $\begin{array}{l}\text { Sterol regulatory element } \\
\text { binding protein (SERBP-1a) }\end{array}$ & CCGAGATGTGCGAACTGGAC & TGTCTCCGTTCTCACCCCCA & 129 & 55 \\
\hline $\begin{array}{l}\text { Sterol regulatory element } \\
\text { binding protein (SERBP-1c) }\end{array}$ & GGAGCCATGGATTGCACATT & AGGAAGGCTTCCAGAGAGGA & 191 & 53 \\
\hline $\begin{array}{l}\text { Sterol regulatory element binding } \\
\text { protein (SERBP-2) }\end{array}$ & CACAATATCATTGAAAAGCGCTACG & TTTTTCTGATTGGCCAGCTTCAGCA & 200 & 55 \\
\hline$\beta$-Actin & CTATGAGCTGCCTGACGGTC & AGTTTCATGGATGCACAGG & 115 & 53 \\
\hline
\end{tabular}

\section{Results}

\section{Experiment 1}

Faecal dry weight in rats fed the AL-27 diet was significantly lower than those in rats fed other test diets. The digestibility of starch and RS in the small intestine was as follows: AL-27 $\gg$ AL-54 > AL-79, AL-62 > AL-86 > AL-76. The digestibility of starch in the small intestine decreased with increasing intakes of amylose and RS (Fig. 1; Table 3).

\section{Experiment 2}

Body weight gain in rats fed the AL-27 diet was significantly higher than that in rats fed the AL-62 diet, and tended to be higher than rats fed the AL-0, AL-54, AL-76, AL-79 and AL-86 diets (Table 4). Food intake was not affected by diet. Apparent starch digestibility was as follows: AL-0, AL-27 > AL-54, AL-62, AL-79, AL-86 > AL-76. Apparent starch digestibility and body weight gain decreased and tended to decrease with increasing RS intake $(r-0.795$, $P=0.0327 ; r-0.748, P=0.0533)$. Plasma total-C concentration was the lowest in rats fed the AL-79 diet, and in rats fed the AL-62, AL-76 and AL-86 diets it was significantly lower than in rats fed AL-27. The concentration of plasma total-C decreased with increasing RS intake $(r-0.835$, $P=0.0193)$. Plasma TAG concentrations in rats fed the AL-62 and AL-79 diets were significantly lower than those in rats fed the AL-0 and AL-27 diets, but those in rats fed the AL-54, AL-62 and AL-86 diets were not. Liver weight was as parallel as body weight gain. The concentration of liver total lipids in rats fed the AL-76 diet was significantly lower than that in rats fed the AL-27 diet, but those in rats
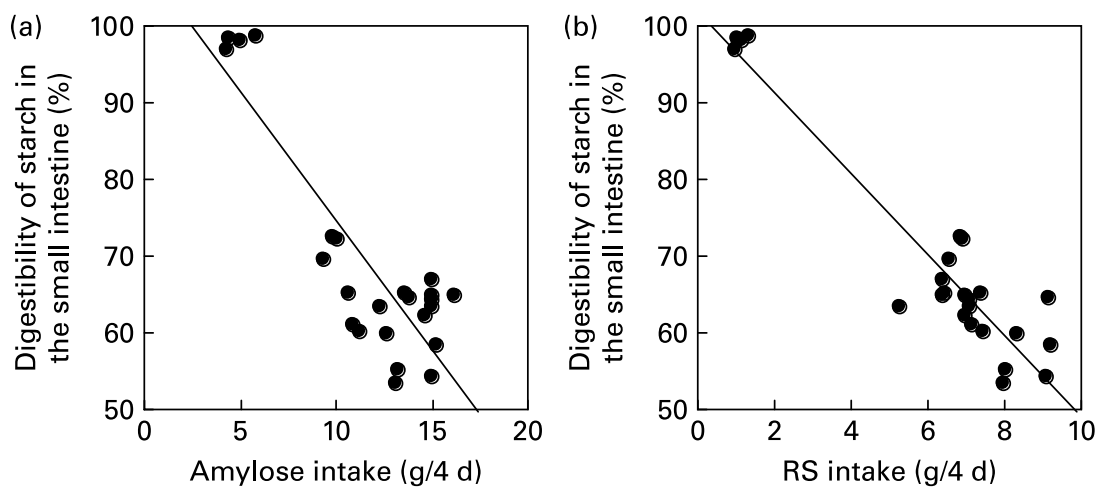

Fig. 1. Correlations between (a) digestibility of starch in the small intestine and amylose intake $(r-0.921, P=0.009)$ and (b) digestibility of starch in the small intestine and resistant starch (RS) intake $(r-0.970, P=0.001)$. 
Table 3. Digestibilities of starch and resistant starch (RS) in the small intestine*

(Mean values and standard deviations)

\begin{tabular}{|c|c|c|c|c|c|c|c|c|c|c|c|c|}
\hline & \multicolumn{12}{|c|}{ Dietary groups } \\
\hline & \multicolumn{2}{|c|}{$A L-27$} & \multicolumn{2}{|c|}{ AL-54 } & \multicolumn{2}{|c|}{ AL-62 } & \multicolumn{2}{|c|}{ AL-76 } & \multicolumn{2}{|c|}{ AL-79 } & \multicolumn{2}{|c|}{ AL-86 } \\
\hline Body weight gain (g/14 d) & 33 & 4 & 29 & 4 & 29 & 4 & 26 & 6 & 28 & 4 & 25 & 9 \\
\hline $\begin{array}{l}\text { Food intake }(\mathrm{g} / 14 \mathrm{~d}) \\
\text { Food intake }(\mathrm{g} / \text { last } 4 \mathrm{~d})\end{array}$ & 205 & 14 & 212 & 16 & 218 & 208 & 208 & 11 & 210 & 11 & 204 & 6 \\
\hline $\mathrm{RS}$ & $1 \cdot 1$ & $0 \cdot 1$ & $6 \cdot 9$ & 0.3 & $8 \cdot 0$ & 0.8 & 8.5 & 0.6 & $6 \cdot 9$ & 0.3 & $6 \cdot 2$ & 0.6 \\
\hline $\begin{array}{l}\text { Dry weight of ileorectostomy } \\
\text { effluents (g/last } 4 \mathrm{~d} \text { ) }\end{array}$ & $6 \cdot 0^{\mathrm{a}}$ & 0.6 & $11 \cdot 7^{b}$ & 1.4 & $13 \cdot 9^{b}$ & $2 \cdot 0$ & $13 \cdot 8^{b}$ & $1 \cdot 0$ & $12 \cdot 8^{b}$ & 0.9 & $11 \cdot 8^{\mathrm{b}}$ & 0.7 \\
\hline Starch digestibility (\%)† & $98 \cdot 2^{d}$ & 0.6 & $70 \cdot 3^{c}$ & $3 \cdot 0$ & $61 \cdot 8^{\mathrm{b}}$ & $2 \cdot 4$ & $55 \cdot 5^{\mathrm{a}}$ & 1.9 & $63 \cdot 8^{b}$ & $1 \cdot 1$ & $65 \cdot 3^{\mathrm{bc}}$ & $2 \cdot 8$ \\
\hline RS digestibility (\%)‡ & $80 \cdot 2^{a}$ & $10 \cdot 6$ & $27 \cdot 5^{c}$ & $8 \cdot 3$ & $11 \cdot 1^{b}$ & 3.0 & $6 \cdot 0^{\mathrm{a}}$ & 1.0 & $11 \cdot 4^{b}$ & $2 \cdot 1$ & $9 \cdot 5^{\mathrm{ab}}$ & $2 \cdot 0$ \\
\hline
\end{tabular}

a,b,c,d Mean values within a row with unlike superscript letters were significantly different $(P<0.05)$.

${ }^{*}$ For details of procedures and diets, see the Materials and methods section and Table 1. Rats were fed one of the test diets for $28 \mathrm{~d}(n 6)$.

$\dagger$ (Starch intake - starch in ileorectostomy effluents)/starch intake.

$\ddagger$ (RS intake - RS in ileorectostomy effluents)/RS intake.

fed the AL-54, AL-62, AL79 and AL-86 diets were not. The concentration of liver total lipids decreased with increasing RS intake $(r-0.845, P=0.0167)$. The concentrations of liver total-C and TAG were not affected by diet.

The dry weights of small intestinal content in rats fed the AL-54, AL-62 and AL-76 diets were significantly heavier than those in rats fed the AL-0 and AL-27 diets, but those in rats fed the AL-79 and AL-86 diets were not (Table 5). The dry weight of small intestinal contents exponentially increased with increasing RS intake $(r$ 0.949, $P=0.0011)$. The amounts of bile acids in small intestinal contents in rats fed the AL-54, AL-62, AL-76, AL-79 and AL-86 diets were significantly higher than in rats fed the AL-0 diet, but not in rats fed the AL-27 diet. The amount of bile acids in small intestinal contents increased as the intake of RS increased ( $r$ 0.910, $P=0.0044)$.

The ratios of the CA group/CDCA group in rats fed the AL-62, AL-76, AL-79 and AL-86 diets were significantly higher than those in rats fed the AL-0 and AL-27 diets.

The CA group/CDCA group ratio of bile acids in the small intestinal contents increased with increasing RS intake ( $r 0.840, P=0.0180$ ). The CA group/CDCA group ratio for bile acids in the small intestinal contents increased with increasing level of CYP8B1 mRNA $(r 0.879, P=0.0091)$.

The caecal wall weights in rats fed the AL-62 and AL-76 diets were significantly heavier than those in rats fed the AL-0, AL-27 and AL-86 diets (Table 6). That in rats fed the AL-79 diet was significantly heavier than those in rats fed the AL- 0 and AL- 86 diets. The moisture of caecal content was not affected by diet. The dry weights of caecal content in rats fed the AL-54, AL-62, AL-76, AL-79 and AL-86 diets were significantly heavier than those in rats fed the AL-0 and AL-27 diet. The amounts of bile acids in caecal content were significantly higher in rats fed the AL-54, AL-62 and AL-76 diets than in rats fed the AL- 0 and AL-27 diets.

The amount of total SCFA in caecal contents increased logarithmically with increasing dry weight of caecal contents ( $r 0.908, P=0.0047$ ). The amount of succinic acid in caecal contents was higher in rats fed the AL-76 diet than in rats fed other diets. The amounts of lactic acid in caecal content in rats fed the AL-62, AL-76 and AL-79 diets were significantly higher than those in rats fed the AL-0 and AL-27 diets, but those in rats fed the AL-54 and AL-86 diets were not. The amounts of acetic acid in caecal content in rats fed the AL-54, AL-62, AL-76, AL-79 and AL-86 diets were significantly higher than those in rats fed the AL-0 and AL-27 diets, and that in rats fed the AL-76 diet was significantly higher than that in rats fed the AL-86 diet. The amounts of propionic and $n$-butyric acid in caecal content were significantly higher in rats fed the AL-54, AL-62, AL-76 and AL-86 diets than in rats fed the AL- 0 and AL-27 diets, but was not significantly higher in rats fed the AL-79 diet than in rats fed the AL-27 diet. The amount of succinic acid + lactic acid in caecal contents exponentially increased with increasing RS intake $(P=0.0003)$ and the dry weight of caecal contents $(r$ 0.997, $P<0.0001)$.

Dry weight of faeces extracted per day was not affected by diet. Bile acids extracted in faeces per day was as follows: AL-76, AL-79, AL-86 > AL-54, AL-62 > AL-0, AL-27 dietary group (Table 6). Faecal excretion of bile acids increased with increasing RS intakes $(r 0 \cdot 866, P=0 \cdot 0117)$. The amounts of coprostanol and total neutral sterol were significantly higher in rats fed the AL-62, AL-76, AL-79 and AL-86 diets than in rats fed the AL- 0 and AL-27 diets, but that in rats fed the AL-54 diet was not.

The mRNA levels of farnesoid $\mathrm{X}$ receptor and hydroxymethylglutaryl-CoA reductase were not affected by diet (Table 7). The mRNA levels of acyl-CoA cholesterol acyltransferase 2, apoB, cholesterol 27-hydroxylase, liver X receptor, microsomal TAG transfer protein and SREBP-1a were also not affected by diet (data not shown). The mRNA level of acyl-CoA cholesterol acyltransferase 1 in rats fed the AL-0 diet was significantly higher than those in rats fed the AL-76, AL-79 and AL-86 diets. The mRNA level of CYP7A1 in rats fed the AL-65 diet was significantly higher than those in rats fed the AL-0 and AL-27 diets, but those in rats fed the AL-54, AL-62, AL-79 and AL86 diets were not. The expression of CYP7A1 mRNA increased exponentially as the intake of RS increased ( $r$ 0.811, $P=0.0267)$. The mRNA levels of CYP8B1 in rats fed the AL-76 and AL-79 diets were significantly higher in rats fed the AL-0 and AL-27 diets, but those in rats fed the AL-54 and AL-62 
Table 4. Effects of amylose contents in maize starch on body weight, body weight gain, food intake and food efficiency in ovariectomized rats* (Mean values and standard deviations)

\begin{tabular}{|c|c|c|c|c|c|c|c|c|c|c|c|c|c|c|}
\hline & \multicolumn{14}{|c|}{ Dietary groups } \\
\hline & \multicolumn{2}{|c|}{$A L-0$} & \multicolumn{2}{|c|}{ AL-27 } & \multicolumn{2}{|c|}{ AL-54 } & \multicolumn{2}{|c|}{ AL-62 } & \multicolumn{2}{|c|}{ AL-76 } & \multicolumn{2}{|c|}{ AL-79 } & \multicolumn{2}{|c|}{ AL-86 } \\
\hline & Mean & SD & Mean & SD & Mean & SD & Mean & SD & Mean & SD & Mean & SD & Mean & SD \\
\hline $\begin{array}{l}\text { Body weight gain ( } \mathrm{g} / 3 \text { weeks) } \\
\text { Food intake ( } \mathrm{g} / 3 \text { weeks) }\end{array}$ & $30^{\mathrm{ab}}$ & 5 & $35^{\mathrm{b}}$ & 5 & $27^{\mathrm{ab}}$ & 11 & $20^{\mathrm{a}}$ & 7 & $27^{\mathrm{ab}}$ & 13 & $23^{\mathrm{ab}}$ & 5 & $25^{\mathrm{ab}}$ & 7 \\
\hline Total & 302 & 13 & 329 & 65 & 300 & 34 & 271 & 15 & 280 & 41 & 287 & 12 & 275 & 20 \\
\hline Amylose & 0 & 0 & 26 & 5 & 48 & 5 & 50 & 3 & 64 & 9 & 68 & 3 & 71 & 5 \\
\hline Resistant starch & 1 & 0 & 6 & 1 & 34 & 4 & 33 & 2 & 40 & 2 & 31 & 5 & 30 & 2 \\
\hline Apparent starch digestibility (\%) & $96 \cdot 9^{\mathrm{cd}}$ & 0.1 & $97 \cdot 3^{\mathrm{d}}$ & 0.3 & $96.0^{\mathrm{bcd}}$ & 0.6 & $95 \cdot 1^{\mathrm{b}}$ & 1.2 & $92 \cdot 8^{\mathrm{a}}$ & 1.5 & $95 \cdot 5^{\mathrm{bc}}$ & 0.6 & $95.0^{\mathrm{b}}$ & 0.9 \\
\hline Apparent energy intake $(\mathrm{kJ} / 3$ weeks $) \dagger$ & $4999^{\mathrm{ab}}$ & 215 & $5444^{\mathrm{b}}$ & 1076 & $4773^{a b}$ & 541 & $3792^{\mathrm{a}}$ & 210 & $3785^{\mathrm{a}}$ & 554 & $4054^{a}$ & 170 & $3898^{\mathrm{a}}$ & 283 \\
\hline \multirow{2}{*}{\multicolumn{15}{|c|}{$\begin{array}{l}\text { Plasma lipids (mmol/l) } \\
\text { Cholesterol }\end{array}$}} \\
\hline & & & & & & & & & & & & & & \\
\hline Total & $3.46^{\mathrm{bc}}$ & 0.30 & $3.84^{\mathrm{c}}$ & 0.54 & $3 \cdot 21^{\mathrm{bc}}$ & 0.32 & $3.05^{\mathrm{ab}}$ & 0.53 & $2 \cdot 88^{\mathrm{a}}$ & 0.19 & $2.45^{\mathrm{a}}$ & 0.19 & $2 \cdot 88^{\mathrm{ab}}$ & 0.19 \\
\hline HDL & $2 \cdot 58^{\mathrm{bc}}$ & 0.18 & $2.67^{\mathrm{c}}$ & 0.32 & $2 \cdot 16^{\mathrm{ab}}$ & 0.25 & $2 \cdot 12^{\mathrm{a}}$ & 0.30 & $2 \cdot 03^{\mathrm{a}}$ & 0.28 & $1.79^{\mathrm{a}}$ & 0.16 & $2 \cdot 00^{\mathrm{ab}}$ & 0.19 \\
\hline Non-HDL $\ddagger$ & $0.88^{\mathrm{ab}}$ & 0.26 & $1 \cdot 17^{\mathrm{b}}$ & 0.31 & $1.05^{\mathrm{ab}}$ & 0.16 & $0.93^{\mathrm{ab}}$ & 0.29 & $0.85^{\mathrm{ab}}$ & 0.23 & $0.66^{\mathrm{a}}$ & 0.16 & $0.81^{\mathrm{ab}}$ & 0.26 \\
\hline TAG & $1 \cdot 21^{\mathrm{b}}$ & 0.41 & $1.20^{\mathrm{b}}$ & 0.49 & $0.70^{\mathrm{ab}}$ & 0.21 & $0.57^{\mathrm{a}}$ & 0.23 & $0.84^{\mathrm{ab}}$ & 0.26 & $0.55^{\mathrm{a}}$ & 0.16 & $1.03^{\mathrm{ab}}$ & 0.40 \\
\hline Phospholipids & $3.38^{\mathrm{b}}$ & 0.31 & $3.55^{\mathrm{b}}$ & 0.29 & $2 \cdot 66^{\mathrm{a}}$ & 0.36 & $2.59^{\mathrm{a}}$ & 0.38 & $2 \cdot 71^{\mathrm{a}}$ & 0.52 & $2 \cdot 27^{\mathrm{a}}$ & 0.14 & $2 \cdot 55^{\mathrm{a}}$ & 0.27 \\
\hline Liver weight (g) & $6.91^{\mathrm{ab}}$ & 0.53 & $7 \cdot 34^{\mathrm{b}}$ & 0.43 & $6 \cdot 70^{\mathrm{ab}}$ & 0.82 & $5.97^{\mathrm{a}}$ & 0.51 & $5 \cdot 94^{\mathrm{a}}$ & 0.53 & $6.42^{\mathrm{ab}}$ & 1.02 & $6 \cdot 54^{\mathrm{ab}}$ & 0.50 \\
\hline
\end{tabular}

a,b,c,d Mean values within a row with unlike superscript letters were significantly different $(P<0.05)$.

*For details of procedures and diets, see the Materials and methods section and Table 1. Rats were fed one of the test diets for $28 \mathrm{~d}(n 6)$ fFood intake $x$ energy value $(\mathrm{kJ} / \mathrm{g})$ 
Table 5. Effects of amylose content in diet on dry weight and bile acids in the small intestinal contents in ovariectomized rats* (Mean values and standard deviations)

\begin{tabular}{|c|c|c|c|c|c|c|c|c|c|c|c|c|c|c|}
\hline & \multicolumn{14}{|c|}{ Dietary groups } \\
\hline & \multicolumn{2}{|c|}{ AL-0 } & \multicolumn{2}{|c|}{ AL-27 } & \multicolumn{2}{|c|}{ AL-54 } & \multicolumn{2}{|c|}{ AL-62 } & \multicolumn{2}{|c|}{ AL-76 } & \multicolumn{2}{|c|}{ AL-79 } & \multicolumn{2}{|c|}{ AL-86 } \\
\hline & Mean & $\overline{S D}$ & Mean & SD & Mean & SD & Mean & SD & Mean & $\overline{S D}$ & Mean & SD & Mean & SD \\
\hline \multicolumn{15}{|l|}{ Small intestinal contents } \\
\hline Dry weight (g) & $0.49^{\mathrm{a}}$ & 0.08 & $0.51^{\mathrm{a}}$ & 0.08 & $0.72^{\mathrm{b}}$ & 0.13 & $0.71^{\mathrm{b}}$ & 0.13 & $0.74^{\mathrm{b}}$ & 0.04 & $0.66^{\mathrm{ab}}$ & 0.11 & $0.68^{\mathrm{ab}}$ & 0.09 \\
\hline Bile acids ( $\mu \mathrm{mol} /$ contents) & $68 \cdot 9^{\mathrm{a}}$ & 9.3 & $81 \cdot 1^{\mathrm{ab}}$ & $10 \cdot 1$ & $98 \cdot 9^{\mathrm{b}}$ & $12 \cdot 0$ & $103 \cdot 4^{\mathrm{b}}$ & 18.4 & $95.7^{\mathrm{b}}$ & $9 \cdot 1$ & $94.7^{\mathrm{b}}$ & 11.0 & $93.9^{\mathrm{b}}$ & 6.4 \\
\hline \multicolumn{15}{|l|}{ Composition of bile acid } \\
\hline \multicolumn{15}{|l|}{ CA group (\%) } \\
\hline $\mathrm{CA}$ & $26 \cdot 0^{\mathrm{a}}$ & 8.4 & $27 \cdot 9^{\mathrm{a}}$ & 4.5 & $28.1^{a}$ & 3.9 & $35 \cdot 0^{\mathrm{a}}$ & 8.9 & $42 \cdot 4^{\mathrm{b}}$ & 6.9 & $35.4^{\mathrm{ab}}$ & 4.6 & $36 \cdot 2^{\mathrm{ab}}$ & $6 \cdot 2$ \\
\hline Deoxycholic acid & 1.0 & 0.3 & 0.7 & 0.2 & 1.1 & 0.3 & 1.2 & 0.3 & 1.3 & 0.4 & 1.3 & 0.5 & 0.9 & 0.2 \\
\hline 12-Oxo-chenodeoxycholic acid & $1.6^{\mathrm{ab}}$ & 1.2 & $1.7^{\mathrm{b}}$ & 0.3 & $1.0^{\mathrm{ab}}$ & 0.3 & $0.6^{a}$ & 0.3 & $0.8^{\mathrm{ab}}$ & 0.2 & $1 \cdot 2^{\mathrm{ab}}$ & 0.4 & $0.7^{\mathrm{ab}}$ & $0 . \overline{5}$ \\
\hline 12-Oxo-lithocholic acid & $27 \cdot 1$ & 0.2 & $25 \cdot 3$ & 0.3 & 33.0 & 0.3 & $29 \cdot 8$ & 0.7 & 29.1 & $4 \cdot 2$ & $29 . \overline{5}$ & 0.4 & 31.0 & 0.4 \\
\hline \multicolumn{15}{|l|}{ CDCA group (\%) } \\
\hline CACD & $3.4^{\mathrm{a}}$ & 0.7 & $3.6^{\mathrm{a}}$ & 0.3 & $3.6^{\mathrm{a}}$ & 0.5 & $3.2^{\mathrm{a}}$ & 0.6 & $7 \cdot 3^{\mathrm{b}}$ & 1.4 & $5 \cdot 1^{\mathrm{b}}$ & 0.2 & $5 \cdot 2^{\mathrm{b}}$ & 0.2 \\
\hline$\alpha$-Muricholic acid & $6 \cdot 6^{\mathrm{a}}$ & 1.3 & $6 \cdot 4^{\mathrm{a}}$ & 1.4 & $4 \cdot 6^{\mathrm{a}}$ & 1.1 & $8.5^{\mathrm{ab}}$ & 3.2 & $12 \cdot 8^{\mathrm{b}}$ & 4.5 & $7 \cdot 7^{\mathrm{ab}}$ & 0.5 & $6 \cdot 8^{\mathrm{a}}$ & $2 \cdot 2$ \\
\hline$\beta$-Muricholic acid & 0.2 & 0.1 & 0.4 & 0.2 & 0.3 & 0.1 & 0.2 & 0.1 & 0.2 & 0.1 & 0.2 & 0.0 & 0.2 & 0.1 \\
\hline$\omega$-Muricholic acid & 0.4 & 0.1 & 0.4 & 0.2 & 0.3 & 0.1 & 0.3 & 0.1 & 0.5 & 0.2 & 0.3 & 0.1 & 0.3 & 0.1 \\
\hline Lithocholic acid & 3.0 & 1.0 & 2.5 & 0.4 & 2.9 & 1.0 & 3.3 & 0.6 & 3.0 & 0.6 & 3.9 & $1 \cdot 2$ & $2 \cdot 8$ & 0.4 \\
\hline Hyodeoxycholic acid + ursodeoxycholic acid & $30.1^{\mathrm{c}}$ & $5 \cdot 8$ & $31.1^{\mathrm{c}}$ & $2 \cdot 3$ & $25 \cdot 2^{\mathrm{bc}}$ & 4.6 & $18 \cdot 0^{\mathrm{bc}}$ & 4.4 & $2 \cdot 6^{a}$ & 1.4 & $15 \cdot 5^{\mathrm{b}}$ & 5.4 & $16.0^{\mathrm{b}}$ & 3.6 \\
\hline CA group/CACD group ratio & $1.26^{\mathrm{a}}$ & 0.36 & $1.25^{\mathrm{a}}$ & 0.27 & $1.72^{\mathrm{ab}}$ & 0.32 & $1.98^{\mathrm{b}}$ & 0.32 & $2.79^{\mathrm{c}}$ & 0.31 & $2 \cdot 06^{\mathrm{b}}$ & 0.33 & $2 \cdot 20^{\mathrm{bc}}$ & 0.24 \\
\hline
\end{tabular}

CA, cholic acid; CACD, chenodeoxycholic acid.

a,b,c Mean values within a row with unlike superscript letters were significantly different $(P<0.05)$.

*For details of procedures and diets, see the Materials and methods section and Table 1. Rats were fed one of the test diets for $28 \mathrm{~d}(n 6)$. 
Table 6. Effects of amylose content in diet on caecal tissue weight, and dry weight, bile acids and organic acids in the caecal contents, and faecal excretion in ovariectomized rats (Mean values and standard deviations)

\begin{tabular}{|c|c|c|c|c|c|c|c|c|c|c|c|c|c|c|}
\hline & \multicolumn{14}{|c|}{ Dietary groups } \\
\hline & \multicolumn{2}{|c|}{ AL-0 } & \multicolumn{2}{|c|}{ AL-27 } & \multicolumn{2}{|c|}{ AL-54 } & \multicolumn{2}{|c|}{ AL-62 } & \multicolumn{2}{|c|}{ AL-76 } & \multicolumn{2}{|c|}{ AL-79 } & \multicolumn{2}{|c|}{ AL-86 } \\
\hline & Mean & SD & Mean & SD & Mean & SD & Mean & SD & Mean & SD & Mean & SD & Mean & SD \\
\hline \multicolumn{15}{|l|}{ Caecum } \\
\hline Caecal tissue weight $(\mathrm{g})$ & $0.59^{\mathrm{a}}$ & 0.08 & $0.63^{\mathrm{ab}}$ & 0.15 & $0.98^{\mathrm{abc}}$ & 0.21 & $1.08^{\mathrm{c}}$ & 0.14 & $1 \cdot 38^{\mathrm{C}}$ & 0.21 & $1.06^{\mathrm{bc}}$ & 0.08 & $0.52^{\mathrm{a}}$ & 0.42 \\
\hline \multicolumn{15}{|l|}{ Caecal content } \\
\hline Moisture $(\mathrm{g} / 100 \mathrm{~g})$ & $76 \cdot 0$ & 1.8 & $76 \cdot 7$ & $1 \cdot 1$ & $77 \cdot 0$ & 1.7 & 77.1 & 1.7 & $77 \cdot 0$ & 0.6 & 78.2 & 1.6 & 77.0 & 1.2 \\
\hline Dry weight $(\mathrm{g})$ & $0.52^{\mathrm{a}}$ & 0.1 & $0.60^{\mathrm{a}}$ & 0.06 & $1 \cdot 26^{b}$ & 0.24 & $1.56^{\mathrm{b}}$ & 0.28 & 2.49 & $0.20^{\mathrm{c}}$ & $1.48^{\mathrm{b}}$ & 0.19 & $1.23^{\mathrm{b}}$ & 0.15 \\
\hline Bile acids (mmol/content) & $8 \cdot 15^{\mathrm{a}}$ & $2 \cdot 38$ & $9.40^{\mathrm{a}}$ & $2 \cdot 39$ & $26 \cdot 16^{\mathrm{d}}$ & 9.48 & $24.71^{\mathrm{cd}}$ & $9 \cdot 16$ & $20 \cdot 08^{\mathrm{bcd}}$ & 5.68 & $14 \cdot 14^{\mathrm{abc}}$ & 3.84 & $10.56^{\mathrm{ab}}$ & 2.05 \\
\hline \multicolumn{15}{|c|}{ Organic acids (mmol/content) } \\
\hline Succinic acid & $1 \cdot 4^{\mathrm{a}}$ & $0 \cdot 2$ & $1 \cdot 7^{\mathrm{a}}$ & 0.3 & $6 \cdot 8^{\mathrm{a}}$ & $2 \cdot 7$ & $8.1^{\mathrm{a}}$ & $4 \cdot 1$ & $28.0^{\mathrm{b}}$ & $12 \cdot 5$ & $10 \cdot 0^{\mathrm{a}}$ & 4.3 & $7 \cdot 6^{\mathrm{a}}$ & $7 \cdot 0$ \\
\hline Lactic acid & $7 \cdot 6^{\mathrm{a}}$ & $4 \cdot 2$ & $7 \cdot 8^{\mathrm{a}}$ & $2 \cdot 3$ & $31.8^{\mathrm{ab}}$ & 15.9 & $38.7^{\mathrm{b}}$ & 17.6 & $58 \cdot 3^{\mathrm{b}}$ & 14.6 & $35.5^{\mathrm{b}}$ & 19.6 & $32 \cdot 3^{\mathrm{ab}}$ & 11.3 \\
\hline Acetic acid & $114^{\mathrm{a}}$ & 19 & $129^{a}$ & 35 & $388^{\mathrm{bc}}$ & 97 & $499^{\mathrm{bc}}$ & 122 & $553^{\mathrm{c}}$ & 100 & $447^{\mathrm{bc}}$ & 115 & $359^{\mathrm{b}}$ & 78 \\
\hline Propionic acid & $32^{\mathrm{a}}$ & 9 & $34^{\mathrm{ab}}$ & 8 & $164^{\mathrm{c}}$ & 37 & $157^{\mathrm{c}}$ & 43 & $123^{\mathrm{c}}$ & 28 & $103^{b c}$ & 40 & $123^{c}$ & 56 \\
\hline$n$-Butyric acid & $18^{\mathrm{a}}$ & 6 & $15^{\mathrm{a}}$ & 5 & $216^{\mathrm{c}}$ & 55 & $218^{\mathrm{c}}$ & 93 & $105^{\mathrm{b}}$ & 14 & $78^{\mathrm{ab}}$ & 17 & $181^{\mathrm{C}}$ & 56 \\
\hline Total SCFA $†$ & $164^{\mathrm{a}}$ & 28 & $178^{\mathrm{a}}$ & 46 & $767^{\mathrm{bc}}$ & 133 & $874^{c}$ & 194 & $780^{\mathrm{bc}}$ & 120 & $628^{\mathrm{b}}$ & 102 & $663^{\mathrm{bc}}$ & 89 \\
\hline \multicolumn{15}{|l|}{ Faecal excretion‡ } \\
\hline Dry weight $(\mathrm{g} / \mathrm{d})$ & $1 \cdot 12$ & 0.03 & $1 \cdot 12$ & 0.08 & 1.32 & $0 \cdot 19$ & 1.40 & 0.32 & 1.25 & 0.20 & 1.32 & 0.25 & 1.45 & 0.66 \\
\hline Bile acids $(\mathrm{mmol} / \mathrm{d})$ & $19 \cdot 2^{\mathrm{a}}$ & 0.9 & $19 \cdot 3^{\mathrm{a}}$ & 0.9 & $22.5^{\mathrm{ab}}$ & $3 \cdot 0$ & $24 \cdot 2^{\mathrm{ab}}$ & $3 \cdot 8$ & $27 \cdot 7^{\mathrm{b}}$ & 3.6 & $26 \cdot 4^{\mathrm{b}}$ & 4.0 & $27 \cdot 7^{\mathrm{b}}$ & $2 \cdot 2$ \\
\hline \multicolumn{15}{|l|}{ Neutral sterol $(\mathrm{mmol} / \mathrm{d})$} \\
\hline Coprostanol & 1.06 & 0.09 & 1.09 & 0.20 & 1.44 & 0.37 & 1.37 & 0.26 & 1.19 & 0.34 & 1.44 & 0.21 & 1.42 & 0.20 \\
\hline Cholesterol & $0.27^{\mathrm{a}}$ & 0.08 & $0.36^{\mathrm{a}}$ & 0.08 & $0.63^{\mathrm{ab}}$ & 0.17 & $1.07^{\mathrm{bc}}$ & 0.27 & $1.18^{\mathrm{C}}$ & 0.44 & $0 \cdot 82^{\mathrm{bc}}$ & 0.29 & $1 \cdot 10^{C}$ & 0.23 \\
\hline Total§ & $1.33^{\mathrm{a}}$ & 0.13 & $1.45^{\mathrm{a}}$ & 0.28 & $2 \cdot 07^{\mathrm{ab}}$ & 0.45 & $2 \cdot 44^{\mathrm{b}}$ & 0.34 & $2 \cdot 37^{b}$ & 0.77 & $2 \cdot 26^{\mathrm{b}}$ & 0.48 & $2 \cdot 52^{\mathrm{b}}$ & 0.42 \\
\hline
\end{tabular}

a,b,c,d Mean values within a row with unlike superscript letters were significantly different $(P<0.05)$.

* For details of procedures and diets, see the Materials and methods section and Table 1. Rats were fed one of the test diets for $28 \mathrm{~d}(n 6)$.

$\dagger$ Acetic + propionic + butyric acids.

Faeces were collected on the last $3 \mathrm{~d}$ of the experimental period.

§oprostanol + cholesterol. 
Table 7. Effects of amylose content in diet on mRNA level of genes on cholesterol metabolism in ovariectomized rats (arbitary units)* (Mean values and standard deviations)

\begin{tabular}{|c|c|c|c|c|c|c|c|c|c|c|c|c|c|c|}
\hline \multirow{2}{*}{ Gene† } & \multicolumn{14}{|c|}{ Dietary groups } \\
\hline & \multicolumn{2}{|c|}{ AL-0 } & \multicolumn{2}{|c|}{ AL-27 } & \multicolumn{2}{|c|}{ AL-54 } & \multicolumn{2}{|c|}{ AL-62 } & \multicolumn{2}{|c|}{$A L-76$} & \multicolumn{2}{|c|}{ AL-79 } & \multicolumn{2}{|c|}{ AL-86 } \\
\hline ACAT1 & $0.90^{\mathrm{ab}}$ & 0.20 & $1 \cdot 30^{\mathrm{b}}$ & 0.22 & $0.92^{\mathrm{ab}}$ & 0.28 & $1 \cdot 13^{\mathrm{ab}}$ & 0.34 & $0.83^{a}$ & 0.17 & $0.82^{a}$ & 0.22 & $0.79^{a}$ & 0.18 \\
\hline CYP7A1 & $0.93^{a}$ & 0.30 & $0.99^{a}$ & 0.22 & $1 \cdot 13^{\mathrm{ab}}$ & 0.36 & $1.08^{a b}$ & 0.38 & $1 \cdot 65^{\mathrm{b}}$ & 0.46 & $1.45^{\mathrm{ab}}$ & 0.27 & $1 \cdot 34^{\mathrm{ab}}$ & 0.23 \\
\hline CYP8B1 & $1.49^{a}$ & 0.28 & $2 \cdot 15^{\mathrm{ab}}$ & 0.50 & $2 \cdot 84^{\mathrm{abc}}$ & 0.89 & $3.01^{a b c}$ & 1.06 & $4 \cdot 25^{c}$ & $1 \cdot 26$ & $4 \cdot 29^{c}$ & 0.88 & $3 \cdot 25^{\mathrm{bc}}$ & 0.76 \\
\hline HMG-CoA R & 1.03 & 0.28 & 1.08 & 0.25 & 1.09 & 0.44 & 1.07 & 0.25 & 1.33 & 0.34 & 1.01 & 0.31 & 1.04 & 0.25 \\
\hline LDL-R & 0.96 & 0.14 & $0 \cdot 71$ & 0.12 & 0.82 & 0.23 & 0.67 & 0.18 & 0.75 & 0.21 & 0.64 & $0 \cdot 10$ & 0.75 & 0.24 \\
\hline SREBP-1C & $1 \cdot 26^{c}$ & 0.44 & $1 \cdot 13^{\mathrm{bc}}$ & 0.39 & $0.55^{a}$ & 0.09 & $0.44^{a}$ & 0.17 & $0.50^{\mathrm{a}}$ & 0.18 & $0.72^{\mathrm{ab}}$ & 0.13 & $0.71^{\mathrm{ab}}$ & 0.21 \\
\hline SREBP-2 & $1 \cdot 61^{\mathrm{ab}}$ & 0.48 & $2 \cdot 22^{\mathrm{b}}$ & 0.34 & $1.43^{a}$ & 0.45 & $1 \cdot 23^{a}$ & 0.30 & $1.25^{a}$ & 0.16 & $1 \cdot 23^{a}$ & 0.22 & $1.47^{\mathrm{a}}$ & 0.43 \\
\hline
\end{tabular}

a,b,c Mean values within a row with unlike superscript letters were significantly different $(P<0.05)$.

${ }^{*}$ For details of procedures and diets, see the Materials and methods section and Table 1 . Rats were fed one of the test diets for $28 \mathrm{~d}(n 6)$.

†For details of genes, see Table 2.

diets were not. The mRNA level of SREBP-1c in rats fed the AL-54, AL-62, AL-76 diets were significantly lower than those in rats fed the AL-0 and AL-27 diets. The mRNA level of SREBP-2 in rats fed the AL-54, AL-62, AL-76, AL-79 and AL-86 diets were significantly lower than that in rats fed the AL-27 diet, but were not significantly lower than that in rats fed the AL- 0 diet.

\section{Discussion}

The content of RS in test starches increased with increasing amylose content $(r 0.907, P=0.0048)$, which was in agreement with the result of Brown et al. ${ }^{(19)}$. However, when amylose content further increased from 75.7 to 79.6 and $85.8 \%$, RS content decreased. Particle size of starch granules decreased with increasing amylose content ${ }^{(20,21)}$. Particle surface area of starch granules increase as the particle size of starch granules decrease. Digestibility of starch can be attributed to particle size and surface area ${ }^{(22-24)}$. Therefore, decreased RS content of AL-79 and AL-86 compared to AL-76 would be due to the increased surface area of starch granules.

Low amylose starches are more digestible than high amylose starches ${ }^{(25,26)}$. The higher the amylose content of starch the greater its resistance to digestion because it forms tightly packed granules in cells. Starches with high amylose/low amylopectin content tend to be of the type-B structure, while those with low amylose/high amylopectin content are of either the type-A or intermediate type-C form ${ }^{(27)}$. The study on the $\mathrm{X}$-ray diffraction of maize starches across a series of differing amylose contents $(0-84 \%)$ showed the changes from A to B via $\mathrm{C}$ with an increase in amylose content, the transition occurring at about $40 \%$ amylose $^{(20)}$. Type-A and type-C starches are more digestible than type-B starches ${ }^{(25,28)}$. These show that the digestibility of starch in the small intestine is affected by not only particle size and surface area of starch granule but also structure of the starch.

It is well known that the deficiency of total energy intake immediately leads to the lowering of plasma cholesterol level ${ }^{(29)}$. In the present study, the reduction of energy intake led to the decrease of plasma total-C concentration. Therefore, the decreased concentration of plasma total- $\mathrm{C}$ would depend on the reduction of the energy intake. On the other hand, the following is also considered as a factor of hypocholesterolaemic effect of RS: (1) increased faecal excretion of bile acids; (2) increased biliary production of bile acids; or (3) increased synthesis of fermentation products that affect hepatic cholesterol synthesis ${ }^{(30)}$. Undigested starches can bind bile acids $^{(31)}$. Therefore, an increased faecal excretion of bile acid through a bile acid binding by undigested starches would cause an increased hepatic synthesis of bile acid synthesis, consequently leading to the decrease of plasma total-C concentration. An increased synthesis of bile acid lowers the hepatic cholesterol pool, and this in turn leads to an up-regulation of gene expression and proteolytic activation of SREBP-2. As a consequence of this, SREBP-2 target genes like LDL-receptor and hydroxamethylglutaryl-CoA reductase would be up-regulated, however, they are not. We do not have an answer to this inconsistency now. The last factor is considered controversial, as in vivo propionate concentrations might not be high enough to decrease the activity of hydroxymethylglutaryl-CoA reductase ${ }^{(32,33)}$. In the present study, the expression of hydroxymethylglutaryl-CoA reductase mRNA was not affected by diet. In addition, there is no correlation between the amount of propionic acid in caecal content and the concentration of plasma total-C. Sacquet et al. ${ }^{(34)}$ reported that HAMS lowered the plasma cholesterol concentration in germ-free rats. Therefore, the last factor would hardly take part in the hypocholesterolaemic effect of RS.

Several studies have shown that HAMS reduces plasma TAG concentrations in rats ${ }^{(36-38)}$. A relatively low insulinaemia has been observed in rats fed HAMS ${ }^{(36,39)}$. Feeding a diet rich in HAMS might produce a lower glycaemic response, consequently leading to declined lipogenesis in liver and adipose tissue ${ }^{(35,36)}$. Because newly synthesized fatty acids are preferentially channelled into VLDL, the lipogenic activity of the liver is a key factor in hepatic VLDL-TAG output $^{(40,41)}$. It has been reported that propionate inhibits fatty acid synthesis ${ }^{(42,43)}$ and decreases fatty acid synthetase mRNA level in cultured hepatocytes ${ }^{(44)}$. In the present study, the concentration of plasma TAG and the amount of propionic acid in the caecal content decreased, and increased as the dietary level of RS increased $(r-0.843, P=0.0173$; $r$ 0.853, $P=0.0146)$. Therefore, feeding a diet rich in RS 
might produce lower lipogenesis in liver and lower VLDL secretion, consequently leading to a decreased plasma TAG concentration. However, the key experimental data are lacking that allows assessment of the quantitative contributions of propionic acid to the synthesis and regulation of lipid in vivo. On the other hand, the concentration of plasma TAG is also controlled by the amount of TAG absorbed from the small intestine. The digestion of high amylose starch may be slower than low amylose $\operatorname{starch}^{(35)}$. The slower digestion of starch rich in RS might make the digestion of TAG slow, which might result in a lower concentration of plasma TAG in rats fed a diet rich in RS.

The concentration of liver total lipids increased with increasing concentration of liver TAG $(r 0.895, P=0.0064)$, suggesting that the change in total liver lipids is due to the change in liver TAG. SREBP-1c plays a significant role in the nutritional regulation of hepatic fatty acid synthesis ${ }^{(45)}$. There was significant positive correlation between the level of SREBP-1c mRNA and concentration of liver TAG ( $r-0.832, \quad P=0.020)$. Reduced hepatic lipogenesis, as suggested by a lower hepatic gene level of SREBP-1c, may account for the lower liver lipids concentration.

Two pathways of bile acid synthesis have been identified in the rat model for hepatic bile acid synthesis: classic (neutral) and alternative (acidic). In rats, the classic pathway is the only pathway in which cholesterol is utilized in CA synthesis ${ }^{(54)}$. CYP8B1 is required for the synthesis of $\mathrm{CA}^{(46)}$. The percentage of $\mathrm{CA}$ in bile acids in the small intestinal contents increased with increasing level of CYP8B1 mRNA $(r$ 0.867, $P=0.0115)$. CDCA was a stronger suppressor of the mRNA expression of CYP7A1 than $\mathrm{CA}^{(55,56)}$. Farnesoid $\mathrm{X}$ receptor negatively regulates bile acid production by inhibiting transcription of the CYP7A1 gene ${ }^{(49)}$. Farnesoid $\mathrm{X}$ receptor is activated by bile acids, such as $\mathrm{CDCA}^{(50)}$. Though the level of farnesoid X receptor mRNA was not affected by diet, faecal excretion of bile acids increased exponentially as RS intake increased $(r 0.886, P=0.0078)$. CDCA inhibited cholesterol synthesis ${ }^{(51)}$. Therefore, the higher CA compared with CDCA in the small intestinal contents may be to promote the synthesis of bile acid in order to compensate bile acids excreted into the faeces.

The caecal tissue weight increased with increasing dry weight of caecal contents and amount of succinic acid in caecal contents $(r 0.808, P=0.0279 ; r 0.873, P=0.0104)$. There was a positive correlation between caecal contents and caecal tissue weight in rats fed diets containing retrograded $\operatorname{starch}^{(52)}$. The greater pool size of succinic acid is likely to play a role in stimulating the growth of caecal tissue ${ }^{(9)}$. Therefore, the increase in caecal contents and succinic acid pool size may contribute to the heavier caecal tissue weight.

Succinic acid and lactic acid are intermediates of global fermentation in the gut and are finally metabolized to SCFA by stable gut fermentation ${ }^{(53)}$. Therefore, succinic acid and lactic acid are rarely detected in the hindgut digesta of rats under normal conditions ${ }^{(54)}$. However, the excess accumulation of these acids has been reported in rats fed on indigestible oligosaccharide or HAMS ${ }^{(9,55)}$. The amount of succinic acid in the caecum increased as the dietary level of HAMS increased ${ }^{(56)}$. In the present study, the higher amount of succinic acid or lactic acid in caecal contents was found in rats fed the diet with the high levels of
RS. Under nitrogen-limited conditions, the excess amounts of fermentable carbohydrate in the caecum should lead to production of lactic acid or succinic $\operatorname{acid}^{(9,57)}$. Unlike SCFA, these acids are not well absorbed by the large intestine ${ }^{(58)}$. Therefore, the excess accumulation of these acids in the caecum would depend on an excess production by an imbalance in carbohydrate/protein ratio of caecal content and a very slowly absorption.

Coprostanol is a metabolite of cholesterol, formed by the action of gut microflora, and its presence may indicate fermentation activity in the large intestine. The caecum is the site of vigorous microbial activity and of the microbiological reduction of cholesterol to coprostanol in the rat ${ }^{(59)}$. The coprostanol/cholesterol ratio of neutral sterol in faeces decreased with increasing total amount of organic acids in caecal contents $(r-0.892, P=0.0069)$. The microbial transformation of cholesterol to coprostanol has been related, so far, to only a few species, namely Eubacterium lentum and E. coprostanoligenes ${ }^{(60,61)}$. Therefore, a decreased coprostanol/cholesterol ratio of neutral sterol in faeces may be due to the suppression of the multiplication of the microorganism to reduce cholesterol into coprostanol by an increased amount of total organic acids in the caecal contents.

The faecal excretion of total neutral sterol increased linearly with increasing RS intake $(r 0.918, P=0.0036)$. The bile flow from the liver to the intestine in rats fed the HAMS diet were significantly greater than those in rats fed the normal maize starch diet ${ }^{(62)}$. Therefore, an increased faecal excretion of neutral sterol with increasing RS intake would be due to an increased bile flow.

In conclusion, the amount of RS in test starches increased with increasing amylose content in starch. Food intake was not significantly different among the groups, but the small intestinal digestibility of test starches in ileorectostomized rats decreased with increasing intakes of amylose and RS, and the concentrations of plasma TAG and total-C in ovariectomized rats decreased with increasing intakes of RS. The amount of bile acids in the small intestinal contents and the excretions of bile acids and neutral steroids in faeces increased with increasing RS intake. Starch rich in RS is less digestible and more effective in preventing ovarian hormone deficiencyinduced hyperlipidaemia.

\section{Acknowledgements}

This work was supported, in part, by the Iijima Memorial Foundation. The authors wish to thank Masaru Yotsuzuka and Aaron K. Edwards (Nippon NSC Ltd, Japan) for donating starches. There is not any conflict of interest on this research. This research was supported by the research costs paid by the Ministry of Education, Culture, Sports, Science and Technology of Japan and the grant of the Iijima Memorial Foundation. X. L. planned the design of the experiment, carried out the experimental plan, summarized the experimental results and discussed the experimental results with the other researchers; H. O. advised on all aspects of the experiment and discussed the experimental results; T. K. helped with all aspects of the experiment and discussed the experimental results; and K. E. discussed the design of the experimental plan and the experimental results. 


\section{References}

1. Gevers Leuven JA (1994) Sex steroids and lipoprotein metabolism. Pharmacol Ther 64, 99-126.

2. Shono N, Kumagai S \& Sasaki H (1996) Obesity, glucose and lipid metabolism, and steroid hormones (in Japanese). J Health Sci 18, 21-44.

3. Sullivan TR Jr, Karas RH, Aronovitz M, Faller GT, Ziar JP, Smith JJ, O'Donnell TF Jr \& Mendelsohn ME (1995) Estrogen inhibits the response-to-injury in a mouse carotid artery model. $J$ Clin Invest 96, 2482-2488.

4. Chen SJ, Li H, Durand J, Oparil S \& Chen YE (1996) Estrogen reduces myointimal proliferation after balloon injury of rat carotid artery. Circulation 93, 577-584

5. de Deckere EA, Kloots WJ \& van Amelsvoort JM (1993) Resistant starch decreases serum total cholesterol and triacylglycerol concentrations in rats. $J$ Nutr 123, 2142-2151.

6. de Deckere EA, Kloots WJ \& van Amelsvoort JM (1995) Both raw and retrograded starch decrease serum triacylglycerol concentration and fat accretion in the rat. Br J Nutr 73, 287-298.

7. Ranhotra GS, Gelroth JA \& Leinen SD (1997) Hypolipidemic effect of resistant starch in hamsters is not dose dependent. Nutr Res 17, 317-323.

8. Kishida T, Nogami H, Himeno S \& Ebihara K (2001) Heat moisture treatment of high amylose corn starch increases its resistant starch content but not its physiologic effects in rats. J Nutr 131, 2716-2721.

9. Morita T, Kasaoka S, Ohhashi A, Ikai M, Numasaki Y \& Kiriyama S (1998) Resistant proteins alter caecal short-chain fatty acid profiles in rats fed high amylose cornstarch. $J$ Nutr 128, $1156-1164$

10. Livesey G (1995) The impact of complex carbohydrates on energy balance. Eur J Clin Nutr 49, Suppl. 3, S89-S96.

11. Folch J, Lees M \& Sloane Stanley GH (1957) A simple method for the isolation and purification of total lipides from animal tissue. J Biol Chem 226, 497-509.

12. Carr TP, Andresen CJ \& Rudel LL (1993) Enzymatic determination of triglyceride, free cholesterol, and total cholesterol in tissue lipid extracts. Clin Biochem 26, 39-42.

13. Eneroth P, Hellstrom K \& Sjovall J (1968) A method for quantitative determination of bile acids in human feces. Acta Chem Scan 22, 1729-1744.

14. Sheltaway MJ \& Losowsky MS (1975) Determination of fecal bile acids by an enzymic method. Clin Chem Acta 64, 127-132.

15. Kishida $T$, Ishikawa $H$, Tsukaoka $M$, Ohga $H$, Ogawa $H$ \& Ebihara $\mathrm{K}$ (2003) Increase of bile acids synthesis and excretion caused by taurine administration prevents the ovariectomy-induced increase in cholesterol concentrations in the serum low-density lipoprotein fraction of Wistar rats. J Nutr Biochem 14, 7-16.

16. Liu X, Sawauchi H, Ogawa H, Kishida T \& Ebihara K (2006) Retrograded tapioca starch prevents ovarian hormone deficiency-induced hypercholesterolemia. J Nutr Sci Vitaminol 52, 134-141.

17. Ebihara K, Shiraishi R \& Okuma K (1998) Hydroxypropylmodified potato starch increases fecal bile acid excretion in rats. $J$ Nutr 128, 848-854.

18. Chomczynski P \& Sacchi N (1987) Single-step method of RNA isolation by acid guanidinium thiocyanate-phenol-chloroform extraction. Anal Biochem 162, 156-159.

19. Brown IL, McNaught KJ, Andrews D \& Morita T (2001) Resistant starch: plant breeding, application development and commercial use. In Advanced Dietary Fibre Technology, pp. 401-412 [BV McCleary and L Prosky, editors]. Oxford: Blackwell Science.

20. Cheetham NWH \& Tao L (1998) Variation in crystalline type with amylose content in maize starch granules: an X-ray powder diffraction study. Carbohydr Polym 36, 277-284.
21. Chen P, Yu L, Chen L \& Li X (2000) Morphology and microstructure of maize starches with different amylose/amylopectin content. Starch/Starke 58, 611-615.

22. Snow P \& O'Dea K (1981) Factors affecting the rate of hydrolysis of starch in food. Am J Clin Nutr 34, 2721-2727.

23. Parker R \& Ring SG (2001) Aspects of physical chemistry of starch. J Cereal Sci 34, 1-17.

24. Morita T, Ito Y, Brown IL, Ando R \& Kiriyama S (2007) In vitro and in vivo digestibility of native maize starch granules varying in amylose contents. J AOAC Int 90, 1628-1634.

25. Riley CK, Wheatley AO, Hassan I, Ahmad MH, Morrison EStY \& Asemota HN (2004) In vitro digestibility of raw starches extracted from five yam (Dioscrea spp.) species grown in Jamaica. Starch/Starke 56, 69-73.

26. Lape IM \& Treche S (1994) Nutritional quality of yam (Dioscorea dumentorum and Dioscorea rotundata) flours for growing rats. J Sci Food Agric 66, 447-455.

27. Hoover R (2001) Composition, molecular structure, and physicochemical properties of tuber and root starches: a review. Carbohydr Polym 45, 253-267.

28. El-Harith EH, Dickerson JW \& Walker R (1976) Nutritive value of various starches for the albino rat. J Sci Food Agric 27, 521-526.

29. Truswell AS (1978) Energy balance and serum lipids. Naringsforskning 22, 65-71.

30. Chen W-J, Anderson J \& Jennings D (1984) Propionate may mediate the hypocholesterolaemic effects of certain soluble fibers in cholesterol-fed rats. Proc Soc Exp Biol Med 175, 215-218.

31. Abadie C, Hug M, Kubli C \& Gains N (1994) Effect of cyclodextrins and undigested starch on the loss of chenodeoxycholate in the faeces. Biochem $J$ 299, 725-730.

32. Illman RJ, Topping DL, McIntosh GH, Trimble RP, Storer GB, Taylor MN \& Cheng BQ (1988) Hypocholesterolaemic effects of dietary propionate: studies in whole animals and perfused rat liver. Ann Nutr Metab 32, 95-107.

33. Beaulieu KE \& McBurney MI (1992) Changes in pig serum lipids, nutrient digestibility and sterol excretion during cecal infusion of propionate. J Nutr 122, 241-245.

34. Sacquet E, Leprince C \& Riottot M (1983) Effect of amylomaize starch on cholesterol and bile acid metabolisms in germfree (axenic) and conventional (holoxenic) rats. Reprod Nutr Dev 23, 783-792.

35. Goda T, Urakawa T, Watanabe M \& Takase S (1994) Effect of high-amylose starch on carbohydrate digestive capability and lipogenesis in epididymal adipose tissue and liver of rats. J Nutr Biochem 5, 256-260.

36. Morand C, Levrat MA, Besson C, Demigne C \& Remesy C (1994) Effects of a diet rich in resistant starch on hepatic lipid metabolism in the rat. J Nutr Biochem 5, 138-144.

37. Kasaoka S, Morita T, Ikai M, Ohhashi A \& Kiriyama S (1998) High-amylose cornstarch prevents increased serumlipids and body fat accretion in rats (in Japanese). J Jpn Soc Nutr Food Sci 51, 345-353.

38. Lopez HW, Levrat-Verny MA, Coudray C, Besson C, Krespine V, Messager A, Demigne C \& Remesy C (2001) Class 2 resistant starches lower plasma and liver lipids and improve mineral retention in rats. $J$ Nutr 131, 1283-1289.

39. Byrnes SE, Miller JC \& Denyer GS (1995) Amylopectin starch promotes the development of insulin resistance in rats. $J$ Nutr 125, $1430-1437$.

40. Gibbons GF (1990) Assembly and secretion of hepatic verylow-density lipoprotein. Biochem J 268, 1-13.

41. Arbeeny CM, Meyers DS, Bergquist KE \& Gregg RE (1992) Inhibition of fatty acid synthesis decreases very low density lipoprotein secretion in the hamster. J Lipid Res 33, 843-851. 
42. Demigne C, Morand C, Levrat MA, Besson C, Moundras C \& Remesy C (1995) Effect of propionate on fatty acid and cholesterol synthesis and on acetate metabolism in isolated rat hepatocytes. Br J Nutr 74, 209-219.

43. Lin Y, Vonk RJ, Slooff MJ, Kuipers F \& Smit MJ (1995) Differences in propionate-induced inhibition of cholesterol and triacylglycerol synthesis between human and rat hepatocytes in primary culture. Br J Nutr 74, 197-207.

44. Delzenne NM, Daubioul C, Neyrinck A, Lasa M \& Taper HS (2002) Inulin and oligofructose modulate lipid metabolism in animals: review of biochemical events and future prospects. Br J Nutr 87, Suppl. 2, S255-S259.

45. Horton JD, Goldstein JL \& Brown MS (2002) SREBPs: activators of the complete program of cholesterol and fatty acid synthesis in the liver. J Clin Invest 109, 1125-1131.

46. Chiang JYL (1998) Regulation of bile acid synthesis. Frontiers Biosci 3, 176-193.

47. Taniguchi T, Chen J \& Cooper AD (1994) Regulation of cholesterol $7 \alpha$-hydroxylase gene expression in Hep-G2 cells. $J$ Biol Chem 269, 10071-10078.

48. Ellis E, Axelson M, Abrahamsson A, Eggertsen G, Thorne A, Nowak G, Ericzon BG, Bjorkhem I \& Einarsson C (2003) Feedback regulation of bile acid synthesis in primary human hepatocytes: evidence that CDCA is the strongest inhibitor. Hepatology 38, 930-938.

49. Davis RA, Miyake JH, Hui TY \& Spann NJ (2002) Regulation of cholesterol-7alpha-hydroxylase: BAREly missing a SHP. J Lipid Res 43, 533-543.

50. Parks DJ, Blanchard SG, Bledsoe RK, et al. (1999) Bile acids: natural ligands for an orphan nuclear receptor. Science $\mathbf{2 8 4}$, $1365-1368$

51. Einarsson C, Hillebrant CG \& Axelson M (2001) Effects of treatment with deoxycholic acid and chenodeoxycholic acid on the hepatic synthesis of cholesterol and bile acids in healthy subjects. Hepatology 33, 1189-1193.

52. Verbeek MJ, De Deckere EA, Tijburg LB, Van Amelsvoort JM \& Beynen AC (1995) Influence of dietary retrograded starch on the metabolism of neutral steroids and bile acids in rats. $\mathrm{Br} J$ Nutr 74, 807-820.

53. Macfarlane S \& Macfarlane GT (2003) Regulation of shortchain fatty acid production. Proc Nutr Soc 52, 367-373.

54. Rubinstein R, Howard AV \& Wrong OM (1969) In vivo dialysis of faeces as a method of stool analysis. IV. The organic anion component. Clin Sci 37, 549-564.

55. Hoshi S, Sakata T, Mikuni K, Hashimoto H \& Kimura S (1994) Galactosylsucrose and xylosylfructoside alter digestive tract size and concentrations of cecal organic acids in rats fed diets containing cholesterol and cholic acid. J Nutr 124, 52-60.

56. Kasaoka S, Morita T, Ikai M, Oh-hashi A \& Kiriyama S (1999) Effect of high-amylose cornstarch on fecal excretion in rats (in Japanese). J Jpn Soc Nutr Food Sci 52, 263-270.

57. Macfarlane GT \& Macfarlane S (1993) Factors affecting fermentation reactions in the large bowel. Proc Nutr Soc 52, $367-373$.

58. Umesaki Y, Yajima T, Tohyama K \& Mutai M (1979) Effect of organic acid absorption on bicarbonate transport in rat colon. Pflugers Arch 14, 43-47.

59. Kellogg TF (1973) On the site of the microbiological reduction of cholesterol to coprostanol. Lipids 8, 658-659.

60. Eyssen HJ, Partmentier GG, Compernolle FC, De Pauw G \& Piessens-Denef M (1973) Biohydrogenation of sterol by Eubacterium ATCC 21,408-nova species. Eur J Biochem 36, 411-421.

61. Sadzikowski MR, Sperry JF \& Wilkins TD (1977) Cholesterolreducing bacterium from human feces. Appl Environ Microbiol 34, 355-362.

62. Kishida T, Nogami H, Ogawa H \& Ebihara K (2002) The hypocholesterolemic effect of high amylose cornstarch in rats is mediated by an enlarged bile acid pool and increased fecal bile acid excretion, not by cecal fermented products. $J$ Nutr 132, 2519-2524.

63. Reeves PG, Nielsen FH \& Fahey GC Jr (1993) AIN-93 purified diets for laboratory rodents: final report of the American Institute of Nutrition ad hoc writing committee on the reformulation of the AIN-76A rodent diet. J Nutr 123, 1939-1951. 